\title{
ISOLATION OF FUNGI FROM THE GASTROINTESTINAL TRACT OF INDIGENOUS CHICKEN
}

\author{
T. Yudiarti ${ }^{1}$, V. D.Yunianto B.I. ${ }^{1}$, R. Murwani ${ }^{1}$ and E. Kusdiyantini ${ }^{2}$ \\ ${ }^{1}$ Faculty of Animal Agriculture, Diponegoro University, \\ Tembalang Campus, Semarang 50275 - Indonesia \\ ${ }^{2}$ Faculty of Mathematic and Science, Diponegoro University, \\ Tembalang Campus, Semarang 50275 - Indonesia \\ Corresponding E-mail: tyudiarti@yahoo.co.id
}

Received October 26, 2011; Accepted April 24, 2012

\begin{abstract}
ABSTRAK
Saluran pencernaan ayam merupakan salah satu tempat yang dapat dijumpai berbagai jenis fungi.Tujuan penelitian ini adalah mengisolasi fungi dari saluran pencernaan ayam kampung. Sampel saluran pencernaan diperoleh dari 5 ekor ayam dengan umur 4 hari, 1 minggu dan 2 bulan yang diperoleh dari satu peternakan ayam kampung di Yogyakarta. Media yang digunakan untuk mengisolasi fungi adalah media Potato Dextrose Agar (PDA). Hasil isolasi dari sampel ayam dengan 3 umur yang berbeda adalah 50 isolat murni fungi dengan rincian masing-masing umur yaitu 4 hari, 1 minggu dan 2 bulan adalah 5, 10, dan 35 isolat. Jumlah isolat terbanyak diperoleh dari bagian ileum, diikuti dengan sekum, jejenum dan duodenum. Kelima puluh isolat yang diperoleh tersebut dapat diidentifikasikan ke dalam 7 spesies yaitu Aspergillus fumigatus, Aspergillus niger, Chrysonilia crassa, Mucor circinelloides, Mucor sp, Rhizopus oligosporus dan Rhizopus oryzae.

Kata kunci: ayam kampung, fungi, isolasi, saluran pencernaan
\end{abstract}

\begin{abstract}
Gastrointestinal tract of chicken is a place in which many kinds of fungi can be found. The aim of the research was to isolate fungi from the gastrointestinal tract of the indigenous chicken (Ayam Kampung). The chicken samples were four days, one week and two months old and were sampled from chicken farm located in Yogyakarta. Potato dextrose agar (PDA) medium was used to grow the fungi. Fifty pure isolates of fungi were found from three different ages, those were four days, one week and two months old chicken were 5, 10 and 35 isolates respectively. The largest number of isolate was found in ileum, then followed by caecum, jejenum and duodenum. The fifty isolate of fungi belonged to seven species, those were Aspergillus fumigatus, Aspergillus niger, Chrysonilia crassa, Mucor circinelloides, Mucor sp, Rhizopus oligosporus and Rhizopus oryzae.

Keyword: fungi, gastrointestinal tract, indigenous chicken, isolation
\end{abstract}

\section{INTRODUCTION}

There are two kinds of microbes which can be found in the gastrointestinal tract of chicken, one of them is fungi. Fungi constitute a group of living organisms devoid of chlorophyll. They resemble simple plant, but they do not have stem, root or leaves, nor vascular system, as plant have. Fungi have a definite cell wall, they are usually nonmotile, although they may have motile reproductive cells and they reproduce spore. They can live in the gastrointestinal tract of chicken (Alexopoulos and Mims, 1979; Kompiang et al., 2006; Lumpkins et al., 2010). Adegunloye (2006) has found fungi in the gastrointestinal tract, those were Aspergillus and Rhizopus.

Distribution of microbe in the gastrointestinal tract is different among one part to another. Gabriel et al. (2006) found that there were two parts of gastrointestinal tracts (crop and caecum), in which can be found many kinds and large number of microbes. Romach et al. (2004) showed that the place where the more existences of microbe were in small intestine and caecum. Bjerrum et al. (2006) stated that the chicken ileum was dominated by lactobacilli, whereas in caecum was found more diverse microbial community

According to Lumpkin et al. (2010) that the 
introduction of microbe into the gastrointestinal tract can occur in a prehatch state before the chick is exposed to the environment outside the shell. There are several factors that can influence the microbe population such as different feed ingredients and subtherapeutic levels of antibiotics in their diets. Interestingly, it has been reported that when hens are fed different diets it appears to affect their genetics and that is passed on to the chick (Rebel et al., 2006 in Lumpkin et al., 2010). The colonization of microbe will be continously done until the population in the gastrointestinal tract is on balance, it means that the microbes do not injured the host which they are living on. But, Lan et al. (2005) stated that the normal intestinal microflora of the small intestine, caecum, and large intestine in chicken develop after hatching. The complexity of chicken gastrointestinal tract microbe gradually increased from day 1 to 19 of life (Magdalena et al., 2011). According to Murwani (2008), the population of the microbe in the gastrointestinal tract will stable when the chicken ages get two to three weeks old. The microbial community is established in the small intestine within approximately two weeks and in caecum needs 6- 7 weeks (Lan et al., 2005).

The obyective of this research was to isolate fungi from the gastrointestinal tract of the indigenous chicken. Because the microbial community still develop after hatching until some weeks, the age of the chicken samples were four days, one week and two months old.

\section{MATERIALS AND METHODS}

The research was done in Microbiology Laboratory of Faculty of Animal Agriculture and Faculty of Science and Mathematics, Diponegoro University. Chicken samples were taken from farm which was located in Yogyakarta. The chicken ages were four days, one week and two months old. The isolation used potato dextrose agar medium and in the medium was added with chloramfenikol antibiotic. Fungi were isolated from the gastrointestinal tract using non selective methods modified by Warcup (Dhingra and Sinclair, 1985; Gam et al., 1987) and direct isolation technique. All isolates then were identified.

\section{Preparation of Potato Dextrose Agar (PDA) Medium}

Two hundreds grams of peeled and sliced potatoes were put in $1 \mathrm{~L}$ of water then boiled until the potatoes became soft. The solution was strained through cheesecloth and adjusted filtrate to $1 \mathrm{~L}$, then it was added $20 \mathrm{~g}$ of sucrose and $17 \mathrm{~g}$ of agar powder prior to autoclaved. Two hundreds and fifty milli grams of chloramphenicol antibiotic was added into the solution and shaked thoroughly. The $10 \mathrm{~mL}$ of the solution was taken and put into a dish (Dingra and Sinclair, 1985, Yudiarti et al., 2010)

\section{Isolation of Fungi from The Gastrointestinal Tract of The Indigenous Chicken}

Firstly, the liquid from small intestine and caecum was put directly on to PDA on plate then incubated at the temperature $40^{\circ} \mathrm{C}$ for 48 hours. Purification must always be done for all plates until each plate only contained one fungus (Dhingra and Sinclair, 1985; Gam et al., 1987).

\section{Identification of All Isolates}

Fungi identification was conducted in macroscopic and microscopic. The macroscopic examination was by the presence of fungal growth in a petri dish and those was often be confirmed directly with the naked eye. The microscopic examination was made by slide preparation to see under the microscope of the hypha, sporangia, oogonia and reproduction structures. All isolates were identified using the key of Ganjar et al. (1999) and Samson et al. (2004).

\section{RESULTS AND DISCUSSION}

\section{Isolation of Fungi}

The isolation of fungi from the four days old chicken was found 5 isolates, as followed: 2 isolates from small intestine and 3 isolates from caecum (Table 1). The isolation of fungi from the one week old chicken was found 10 isolates, those were small intestine 4 isolates and caecum 6 isolates (Table 2).

Results showed that the isolation of fungi from the two months old chicken was found 35 isolates, those were obtained from duodenum, jejenum, ileum and caecum being 6, 7, 13 and 9 isolates, respectively (Table 3 ).

The isolation of fungi from the four days, one week and two months old chicken were found 5, 10 and 35 isolates, respectively. The result indicated that the increase the chicken age, the higher the number of fungi in gastrointestinal tract. As mentionwd by Barnes (1972), Yegani and Krover (2008) and Magdalena et al. (2011) 
Table 1. The Isolate of Fungi from Gastrointestinal Tract of Four Days Old Chicken

\begin{tabular}{cccc}
\hline $\begin{array}{c}\text { Chicken } \\
\text { Sample }\end{array}$ & $\begin{array}{c}\text { Small } \\
\text { Intestine }\end{array}$ & Caecum & Total \\
\hline 1 & - & 1 & 1 \\
2 & 1 & - & 1 \\
3 & - & 1 & 1 \\
4 & - & 1 & 1 \\
5 & 1 & - & 1 \\
\hline Total & 2 & 3 & 5 \\
\hline
\end{tabular}

Table 2. The Isolate of Fungi from Gastrointestinal Tract of One Week Old Chicken

\begin{tabular}{cccc}
\hline $\begin{array}{c}\text { Chicken } \\
\text { Sample }\end{array}$ & $\begin{array}{c}\text { Small } \\
\text { Intestine }\end{array}$ & Caecum & Total \\
\hline 1 & - & 2 & 2 \\
2 & 2 & - & 2 \\
3 & - & 2 & 2 \\
4 & - & 2 & 2 \\
5 & 2 & - & 2 \\
\hline Total & 4 & 6 & 10 \\
\hline
\end{tabular}

that the population of microbe in gastrointestinal tract increases and complex if the chicken age increase. Increasing of the chicken age, it also increases in feed consume and feed is one of materials that brings the microbe comes into the body of chicken (Michaela, 2008; Lee and Salminen, 2009; Torok et al., 2011).

The results showed that the number of isolates found in each part was different and greatest number of isolate was found in ileum (Table 3). Torok et al. (2008) also found that the community of microbe in each part of the gastrointestinal tract was varied. Wise and Siragusa (2007) reported that the microbial community were the most pronounced in the ileal region. The differences were caused by the different environmental condition, such as $\mathrm{pH}$ as explained by Yamanaka (2003). The $\mathrm{pH}$ in ileum was neutral to slightly alkaline and those was favorable for fungi growth. The number of isolate of fungi which was found in duodenum was the fewest one (Table 3), this was agreed with the finding of Gabriel et al. (2006) and Romach et al.
(2004). These were also caused by the environmental condition in the duodenum was quite acid and fungi could not growth in that condition (Yamanaka, 2003).

Fifty isolates of fungi were obtained from this research. The result showed that in gastrointestinal tract of chicken was not only found some bacteria but also fungi.

Isolation of fungi from the five samples of the indigenous chicken found fifty isolates. The results showed that there was a big population of fungi in gastrointestinal tract of indigenous chicken. The finding was in agree to the Kim and Mundt (2011) found that in the digestive tract of chicken contains a very large numbers of microbes with a high diversity. In addition, it was reported by Forder et al. (2007) and Michael et al. (2010) that in the intestines was found a complex microbe that plays an important role in the growth and health of the chicken.

\section{Identification of Isolate of Fungi}

Result of the identification of all isolates were 19 genus Rhizopus, 24 genus Aspergillus, 5 genus Mucor and 2 genus Chrysonilia. Further identification of the genus were found 7 spesies, those were Aspergillus fumigatus (Figure 1), Aspergillus niger (Figure 2), Chrysonilia crassa (Figure 3), Mucor circinelloides (Figure 4), Mucor sp (Figure 5), Rhizopus oligosporus (Figure 6), and Rhizopus oryzae (Figure 7).

The characters of each species were 1) Aspergillus fumigatus: colony on PDA at $40^{\circ} \mathrm{C}$ in 24 hours attained a diameter $0.8-1.0 \mathrm{~cm}$, consisted of a dense of dark green conidiophores, 2) Aspergillus niger: colony on PDA at $40^{\circ} \mathrm{C}$ in 24 hours attained a diameter $0.2-0.5 \mathrm{~cm}$, consisted of a dense of dark brown to black conidiophores, 3) Chrysonilia crassa: colony on PDA at $40^{\circ} \mathrm{C}$ in 24 hours attained a diameter $4-4.5 \mathrm{~cm}$, conidia one celled in chains and the colour was pinkish to orange, 4) Mucor circinelloides: colony on PDA at $40^{\circ} \mathrm{C}$ in 24 hours attained a diameter $4-4.5$ $\mathrm{cm}$, the colour was greyish-green, 5) Mucor $s p$ : colony on PDA at $40^{\circ} \mathrm{C}$ in 24 hours attained a diameter $2.0-2.3 \mathrm{~cm}$, the colour was white, 6 ) Rhizopus oligosporus: colony on PDA at $40^{\circ} \mathrm{C}$ in 24 hours attained a diameter $2.6-3.5 \mathrm{~cm}$, the colour was pale brownish-grey, 7) Rhizopus oryzae: colony on PDA at $40^{\circ} \mathrm{C}$ in 24 hours attained a diameter $0.7-1 \mathrm{~cm}$, the colout was whitish become brownish-grey.

There were two kinds of microbes that always apparent and exist in all parts of the 
Table 3. The Isolate of Fungi from the Chicken with Two Months Old

\begin{tabular}{cccccc}
\hline Chicken Sample & Duodenum & Jejenum & Ileum & Caecum & Total \\
\hline 1 & 1 & 1 & 2 & 1 & 5 \\
2 & 1 & 1 & 3 & 1 & 6 \\
3 & 1 & 1 & 2 & 2 & 6 \\
4 & 1 & 2 & 3 & 2 & 8 \\
5 & 2 & 2 & 3 & 3 & 10 \\
\hline Total & 6 & 7 & 13 & 9 & 35 \\
\hline
\end{tabular}

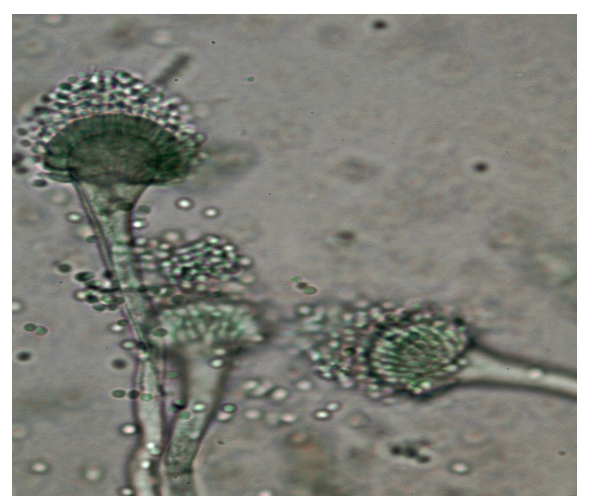

Figure 1. Aspergillus fumigatus

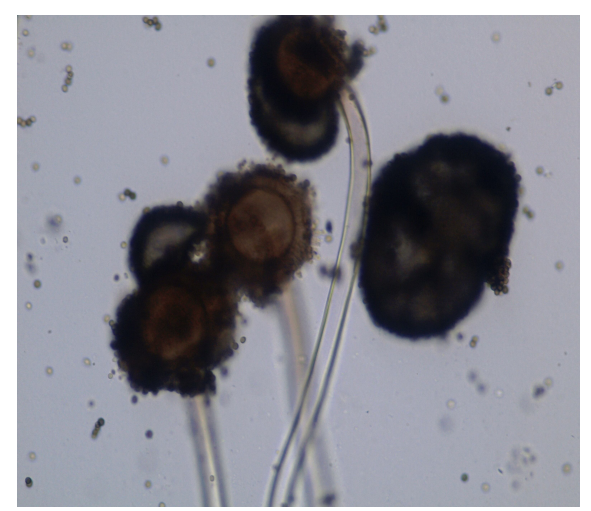

Figure 2. Aspergillus niger

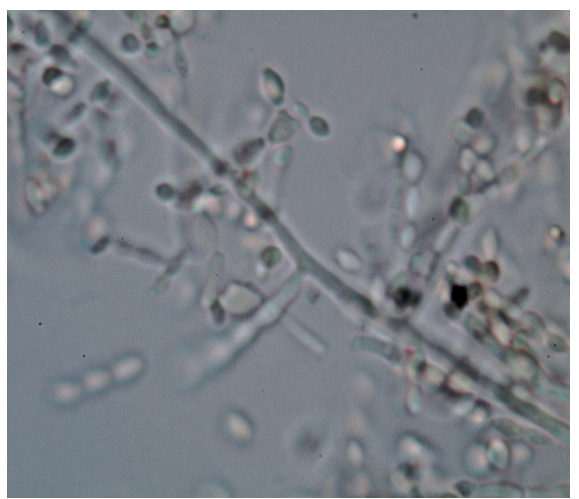

Figure 3. Chrysonilia crassa

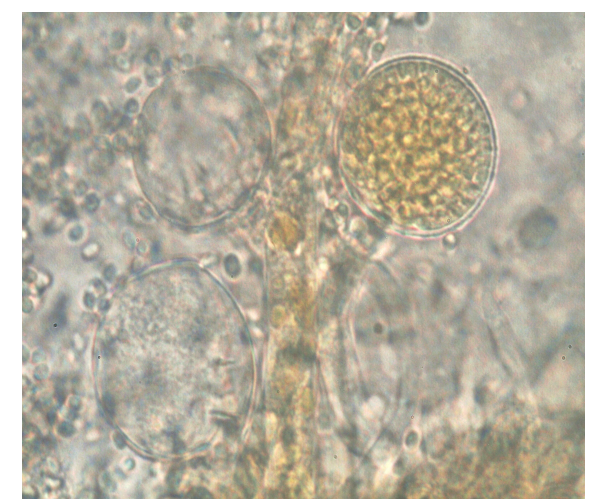

Figure 4. Mucor circinelloides

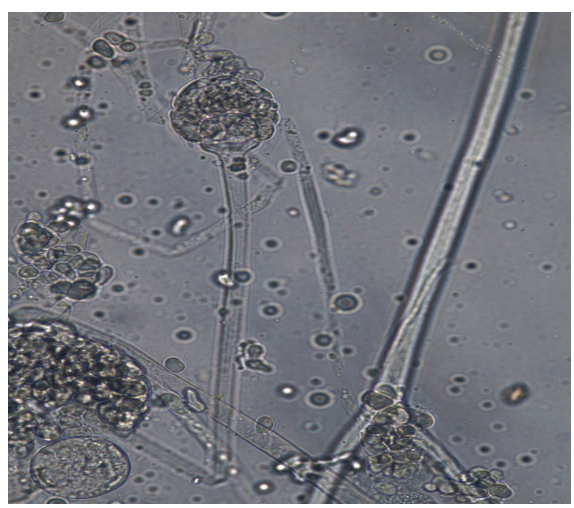

Figure 5. Mucor sp

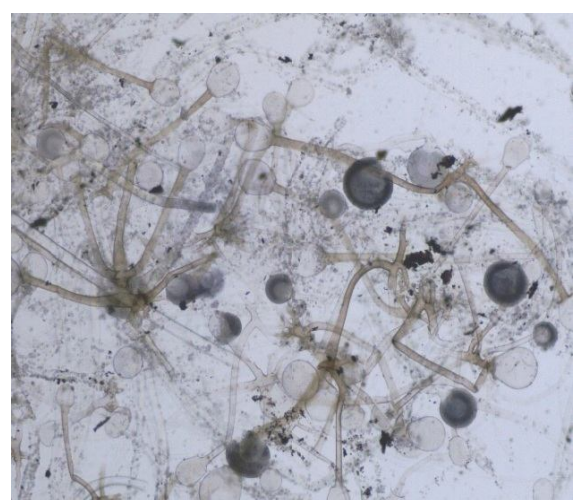

Figure 6. Rhizopus oligosporus 


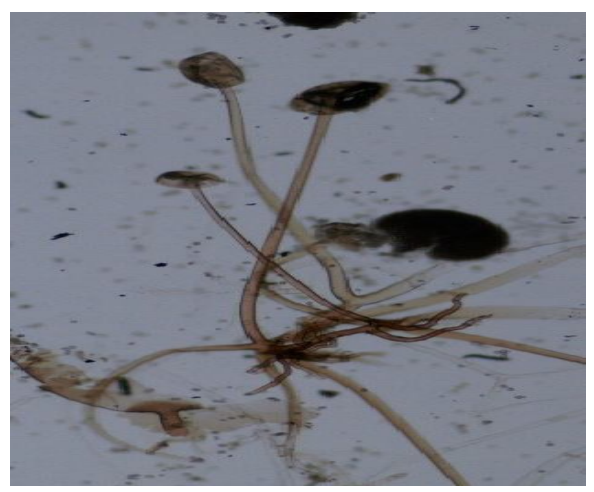

Figure 7. Rhizopus oryzae

gastrointestinal tract of three different ages of chicken samples, those kinds were Aspergillus $s p$ and Rhizopus sp. This finding was same as results of the research by Adegunloye (2006). The reason was because the two fungi were belong to ubiquotus fungi. According to Samson et al. (2004) that the fungi which was belong to ubiquotus fungi could grow easily in any condition and any media.

\section{CONCLUSION}

The isolation of fungi from the four days, one week and two months old chicken were found 5, 10 and 35 isolates, respectively. Ileum was the part of the gastrointestinal tract which was found the largest number of isolate of fungi and duodenum was the fewest one. Identification of all isolates belonged to 7 species, those were Aspergillus niger, Aspergillus fumigatus, Chrysonilia crassa, Mucor circinelloides, Mucor sp, Rhizopus oryzae and Rhizopus oligosporus

\section{REFERENCES}

Alexopoulos, C. J. and C. W. Mims. 1979. Introductory Mycology. Third Edition. John Wiley dan Sons, Singapore.

Adegunloye, D.V. 2006. Microorganism associated with poultry faeces. J. Food Agric. And Environ. 4 (1):41-42

Barnes, E. M. 1972. The avian intestinal flora with particular reference to the possible ecological significance of the Cecal anaerobic bacteria. The American J. Clinical Nutr. 25:1475-1479

Bjerrum, 1., R.M.Engberg, T.D.Leser, B.B.Jensen, K.Finster and K. Pedersen. 2006. Microbial community composition of the ileum and cecum of broiler chickens as revealed by molecular and culture-based techniques. Poult. Sci. 85:1151-1164

Dhingra, O.D. and J.B. Sinclair. 1985. Basic Plant Pathology Methods. CRC Press, Inc. Florida.

Forder, R. E. A., G. S. Howarth, D. R. Tivey and R. J. Hughes. 2007. Bacterial modulation of small intestinal goblet cells and mucin composition during early posthatch development of poultry. J. Poult. Sci. 86:2396-2403

Gabriel, I. M. Lessire, S. Mallet and J. F. Guillot. 2006. Microflora of the digestive tract: critical factors and consequences for poultry. Poult. Sci. 62:499-511

Gam, W., H.A. Van der Aa, A.J. Van der Paats Niterink, R.A. Samson and J.A. Stalpers. 1987. CBS Course of Mycology. Central Bureau Voor Schmimmelcultures. Baarn.

Ganjar, I., R. A. Samson, K. Van den TweelVermeulen, A. Oetari and I. Santoso. 1999. Pengenalan Kapang Tropik Umum. Yayasan Obor Indonesia, Jakarta.

Kim, T. and E. Mundt. 2011. Metagenomic analysis of intestinal microbiomes in chickens. Methods Mol. Biol. 733:185-94.

Kompiang, I.P, Supriyati and S. Guntoro. 2006. Pengaruh Probiotik Biovet Bacillus apiarius pada Performan Ayam Pedaging :Uji Coba Lapangan. Prosiding Seminar Teknologi Peternakan dan Veteriner. Page 646-649.

Lan, Y., M. W. A. Verstegen, S. Stamminga, and B. A. Williams. 2005. The role of the commensal gut microbial community in broiler chickens. Poult. Sci. 61:95-103.

Lee, T. K. and S. Salminen. 2009. Handbook of Probiotics and Prebiotics. Second Edition. A John Wiley dan Sons, Inc., New Jersey.

Lumpkin, B. S, A. B. Batal and M. D. Lee. 2010. Evaluation of the bacterial community and intestinal development of different genetic lines of chickens. Poult. Sci. 89 :1614-621

Magdalena C., H. Hradecka, M. Faldynova, M. Matulova, H. Havlickova, F. Sisak, and I. Rychlik. 2011. Immune response of chicken gut to natural colonization by gut microflora and to Salmonella enterica serovar enteritidis infection. Infect Immun. 79(7): 2755-2763

Michaela, M. 2008. Mikroflora dalam gastrointestinal dan pengaruhnya pada ternak. Buletin Charon Pokphand. (98):5-6

Michael, D.C, Z. Yu, M. C. Nelson, S. J. Oeller, M. S. Lilburn, and H. N. Zerby. 2010. Interrelations between the microbiotas in the litter and in the intestines of commercial 
broiler chickens. Appl. and Environ. Microbiol. p.6572-6582

Murwani, R. 2008. Aditif Pakan. Aditif Alami Pengganti Antibiotik. Unnes Press, Semarang.

Romach, E. A., D. Sklan and Z. Uni. 2004. Microflora ecology of the chicken intestine using 16S ribosomal DNA primers. Poult. Sci. 83:1093-1098.

Samson, R, E. Hoekstra and J. Firsvad. 2004. Introduction to Food and Airborn Fungi. Centraal Bureau voor Schimmelcultures, Utrecht.

Torok, V. A., K. O. Keller, M. Loo and R. J. Hughes. 2008. Application of methods for identifying broiler chicken gut bacterial species linked with increased energy metabolism. Appl. Environ. Microbiol. 74(3):783-791

Torok, V.A., G.E. Allison, N.J. Percy, K. OphelKeller and R.J. Hughes. 2011. Influence of antimicrobial feed additives on broiler commensal posthatch gut microbiota development and performance. Appl. Environ. Microbiol. 77(10):3380-3390

Wise, M.G and G.R.Siragusa. 2007. Quantitative analysis of the intestinal bacterial community in one to three week commercially reared broiler chickens fed conventional or antibiotic free vegetablebased diets. J. Appl. Microbiol. 102:11381149

Yamanaka, T. 2003. The effect of $\mathrm{pH}$ on the growth of saprotrophic and ectomycorrhizal ammonia fungi in vitro. Mycologia. 95(4): 584-589.

Yegani, M. and D. R. Korver. 2008. Factors affecting intestinal health in poultry. Poult. Sci. (87) :2052-2063

Yudiarti, T., Sumarsono, D. W. Widjayanto. 2010. Identification of soil fungi isolated from Alfalfa (Medicago sativa $\mathrm{L}$ ) to find specific fungi which improve the growth of Alfalfa. J.Indonesian Trop. Anim. Agric. 35:197-200 